\title{
Pengaruh Stretching Exercise Terhadap Penurunan Skala Nyeri Sendi Lutut Pada Pasien Osteoartrtis
}

\author{
Edwina R. Monayo, Fenti Akuba \\ Fakultas Olahraga dan Kesehatan Universitas Negeri Gorontalo \\ E-mail: ewi_doc@ung.ac.id
}

\begin{abstract}
ABSTRAK
Osteoartritis merupakan suatu penyakit sendi degeneratif yang terjadi karena proses inflamasi kronis pada sendi dan tulang sekitar sendi. Salah satu penatalaksanaan non Farmakologi yaitu dengan stretching exercise. Stretching Exercise dapat mengurangi nyeri sendi lutut dengan mengunakan tekhnik latihan gerakan tubuh baik secara aktif maupun pasif. Tujuan penelitian untuk mengetahui Pengaruh Stretching Exercise Terhadap Penurunan Skala Nyeri Sendi Lutut pada Pasien Osteoartritis. Jenis penelitian adalah pra eksperiment dengan pretest and postest one group design. Penelitian dilaksanakan Di Puskesmas Kota Selatan Kota Gorontalo. Populasi seluruh pasien Osteoartritis di Puskesmas Kota Selatan Kota Gorontalo dengan Jumlah sampel yang diperoleh dari tekhnik accidental sampling. Hasil penelitian menunjukkan bahwa terdapat pengaruh stretching exercise terhadap penurunan skala nyeri sendi lutut pada pasien Osteoartritis dengan $p$-value $(0,000)<\alpha(0,05)$. Saran diharapkan agar terapi ini dapat diberikan dalam upaya pencegahan serta penanganan nyeri sendi lutut atau gangguan muskuloskeletal.
\end{abstract}

Kata kunci: stretching exercise, nyeri, osteoartritis

\begin{abstract}
Osteoarthritis is a degenerative joint disease that occurs due to chronic inflammatory processes in the joints and bones around the joints. One of the non-pharmacological management is stretching exercise. Stretching Exercise can reduce knee joint pain by using body movement training techniques both actively and passively. The aim of the study was to determine the effect of stretching exercise on the reduction of the scale of knee joint pain in patients with osteoarthritis. The population of all Osteoarthritis patients in the South City Health Center of Gorontalo City with the number of samples obtained from the accidental sampling technique. There is an effect of stretching exercise on decreasing the knee joint pain scale in patients with Osteoarthritis with p-value $(0,000)$ $<\alpha(0.05)$. This therapy can be given in an effort to prevent and treat knee joint pain or musculoskeletal disorders.
\end{abstract}

Keywords: stretching exercise, pain, osteoartritis

\section{PENDAHULUAN}

Osteoartritis (OA) merupakan suatu penyakit yang berkembang dengan perlahan tetapi merupakan penyakit aktif degenerasi kartilago artikular yang berhubungan dengan simptom-simptom seperti nyeri sendi, kekakuan, dan keterbatasan pergerakkan (Padila, 2013). Handono (2013), menambahkan gejala khas dari penyakit osteoartritis berupa nyeri pada persendian. Nyeri sendi adalah suatu peradangan sendi yang ditandai dengan pembengkakan sendi, warna kemerahan, panas, nyeri dan terjadinya gangguan gerak. Pada keadaan ini pasien akan sangat terganggu, apabila lebih dari satu sendi yang terserang. Nyeri pada 
persendian akan berdampak pada keterbatasan mobilitas pasien tetapi dikhawatirkan akan terjadi hal yang paling ditakuti apabila nyeri tidak tertangani dengan baik yaitu menimbulkan kecacatan seperti kelumpuhan dan gangguan aktivitas hidup sehari-hari (Lukman \& Ningsih, 2012).

\begin{tabular}{|c|c|}
\hline Menurut & World \\
\hline $\begin{array}{l}\text { nization } \\
\text { artritis }\end{array}$ & $\begin{array}{l}\text { (WHO) tahun } \\
\text { merupakan }\end{array}$ \\
\hline
\end{tabular}
muskuloskeletal yang paling sering terjadi. Prevalensi osteoartritis lutut di dunia yaitu sebesar $3.8 \%$ dan osteoartritis pinggul sebesar $0.85 \%$. Tidak dijumpai perubahan yang bermakna terhadap prevalensi osteoartritis dari tahun 1990 hingga 2010. Sementara, prevalensi rheumatoid arthritis di dunia yaitu sebesar $0.24 \%$ tanpa dijumpai perubahan bermakna selama 20 tahun lamanya. WHO juga mengungkapkan bahwa prevalensi nyeri rematik di beberapa negara Asean adalah, $26.3 \%$ Bangladesh, 18.2\% India, 23.6$31.3 \%$ Indonesia, $16.3 \%$ Filipina, dan $14.9 \%$ Vietnam.

Data Riset Kesehatan Dasar (Riskesdas) tahun 2013, di Indonesia pada tahun 2007-2013, prevalensi rematik dapat ditemui pada usia lebih sama dengan atau $>15$ tahun terdapat $30.3 \%$ pada tahun 2007 dan mengalami penurunan pada tahun 2013 yaitu menjadi 24.7\%. Sedangkan data penderita rematik di Indonesia berdasarkan jenis kelamin cenderung terjadi pada perempuan dibandingkan laki-laki dengan prevalensi 34\%. Sementara itu, di Provinsi Gorontalo, prevalensi penyakit osteoartritis ditemukan sebanyak 79.5 dan diperkirakan data ini akan meningkat setiap tahunnya (Riskesdas, 2013).

Saat ini banyak terdapat penelitian baru yang dapat digunakan sebagai upaya dalam penurunan skala nyeri sendi lutut yaitu dengan terapi non-farmakologi salah satunya adalah stretching exercise. Yandri (2011) mengemukakan bahwa Stretching Exercise merupakan salah satu terapi latihan untuk mempercepat penyembuhan dari suatu injuri/penyakit tertentu yang dalam pelaksanaanya mengunakan latihan - latihan gerakan tubuh baik secara aktif maupun pasif (dalam Sari dan Pamungkas, 2011). Stretching merupakan suatu aktivitas meregangkan otot untuk meningkatkan fleksibilitas otot dan jangkauan gerakan persendian. The Crossfit Journal Article (2016) mengemukakan bahwa stretching sangat efektif dilakukan untuk meningkatkan fleksibilitas otot dan sendi sehingga dapat memberikan efek penurunan atau hilangnya rasa nyeri pada persendian. Latihan ini juga dapat meningkatkan aliran darah, juga memperkuat tulang (dalam Rahmiati, 2017).

Fenomena di ruang rawat jalan yang sering dijumpai di lapangan adalah perawat seolah hanya terfokus pada intervensi farmakologinya saja. Pasien mengeluh sudah capek untuk selalu minum obat dan mengatakan sudah tidak mau lagi untuk mengkonsumsi obatnya lagi karena merasa tidak kunjung sembuh. Dari hasil studi pendahuluan ini juga didapatkan belum pernah ada penatalaksanaan non farmakologi gangguan nyeri sendi lutut pada pasien osteoartritis. Peneliti merasa perlu dilakukan 
adanya upaya untuk memperbaiki kondisi pasien tersebut.

\section{METODE}

Jenis penelitian ini menggunakan Metode Pre-Eksperimen dengan menggunakan rancangan penelitian One-Group PretestPosttest Design. Penentuan sampel dilakukan dengan cara accidental sampling, jumlah sampel sebanyak 15 orang. Analisis data menggunakan uji ttest dengan tingkat kemaknaan $\alpha(0,005)$.

Puskesmas Kota Selatan Kota Gorontalo berada di ibukota Provinsi Gorontalo yang dibangun pada tahun 1969 dan dimanfaatkan sebagai pusat kesehatan masyarakat utama atau tempat pelayanan kesehatan di Kota Selatan Kota Gorontalo. Puskesmas Kota Selatan Kota Gorontalo beralamatkan di Jalan Moh. Yamin, Limba B, Kota Selatan, Kota Gorontalo.

HASIL

Tabel 1. Distribusi Demografi Responden.

\begin{tabular}{|l|c|c|}
\hline \multicolumn{1}{|c|}{ Variabel } & (n) & $(\mathbf{\% )}$ \\
\hline Usia & & \\
$25-35$ tahun & 6 & 40 \\
36-45 tahun & 4 & 26.7 \\
$46-55$ tahun & 2 & 13.3 \\
$56-65$ tahun & 3 & 20 \\
\hline Total & $\mathbf{1 5}$ & $\mathbf{1 0 0}$ \\
\hline Jenis Kelamin & & 40 \\
Laki-laki & 6 & 60 \\
Perempuan & 9 & $\mathbf{1 0 0}$ \\
\hline Total & $\mathbf{1 5}$ & 46.7 \\
\hline Pendidikan Terakhir & & 33.3 \\
SD/Sederajat & 7 & 20 \\
SMP/Sederajat & 5 & $\mathbf{1 0 0}$ \\
SMA/Sederajat & 3 & 60 \\
\hline Total & $\mathbf{1 5}$ & 40 \\
\hline Pekerjaan & & $\mathbf{1 0 0}$ \\
Tidak Bekerja & 6 & \\
Bekerja & 9 & $\mathbf{1 5}$ \\
\hline Total & & \\
\hline
\end{tabular}

Tabel 2. Distribusi Nyeri Responden Sebelum Stretching Exercise (Pretest)

\begin{tabular}{|c|c|c|c|}
\hline \multirow{2}{*}{ No } & \multirow{2}{*}{ Kategori nyeri } & \multicolumn{2}{|c|}{ Sebelum Perlakuan (Terapi Stretching Exercise) } \\
\hline & & $\mathbf{N}$ & $\%$ \\
\hline 1 & Nyeri Ringan & 0 & 0 \\
\hline 2 & Nyeri Sedang & 8 & 53.3 \\
\hline 3 & Nyeri Berat & 7 & 46.7 \\
\hline Total & 15 & 100 & Total \\
\hline
\end{tabular}


Tabel 3. Distribusi Nyeri Responden Sesudah Stretching Exercise (Posttest).

\begin{tabular}{|l|l|l|l|}
\hline \multirow{2}{*}{ No } & \multicolumn{1}{|c|}{ Kategori nyeri } & \multicolumn{2}{c|}{ Sesudah Perlakuan (Terapi Stretching Exercise) } \\
\cline { 3 - 5 } & Nyeri Ringan & 8 & N \\
\hline 1 & Nyeri Sedang & 7 & 53.3 \\
2 & Nyeri Berat & 0 & 46.7 \\
3 & $\mathbf{1 5}$ & $\mathbf{1 0 0}$ & 0 \\
\hline Total & &
\end{tabular}

Tabel 3. Perbedaan Perubahan Skala Nyeri Sendi Lutut pada Pasien Osteoartritis Sebelum dan Sedudah Stretching Exercise

\begin{tabular}{|c|c|c|c|}
\hline \multirow{2}{*}{ Responden } & \multicolumn{2}{|c|}{ Nilai Nyeri Sendi Lutut } & \multirow{2}{*}{ Keterangan } \\
\cline { 2 - 3 } & Sebelum & Sesudah & Menurun \\
\hline Responden 1 & 6 & 2 & Menurun \\
Responden 2 & 6 & 2 & Menurun \\
Responden 3 & 7 & 5 & Menurun \\
Responden 4 & 8 & 4 & Menurun \\
Responden 5 & 8 & 4 & Menurun \\
Responden 6 & 7 & 3 & Menurun \\
Responden 7 & 7 & 4 & Menurun \\
Responden 8 & 6 & 3 & Menurun \\
Responden 9 & 8 & 4 & Menurun \\
Responden 10 & 6 & 3 & Menurun \\
Responden 11 & 6 & 3 & Menurun \\
Responden 12 & 7 & 4 & Menurun \\
Responden 13 & 5 & 3 & Menurun \\
Responden 14 & 6 & 3 & Menurun \\
Responden 15 & 6 & 2 & \\
\hline Rata-rata & $\mathbf{6 . 8 0}$ & $\mathbf{3 . 2 7}$ & \\
\hline
\end{tabular}

Tabel 4. Pengaruh Stretching Exercise terhadap Penurunan Skala Nyeri Sendi Lutut pada Pasien Osteoartritis

\begin{tabular}{|l|l|l|l|l|l|l|}
\hline \multirow{2}{*}{ Variabel } & \multirow{2}{*}{$\begin{array}{c}\text { Pre test } \\
(\text { Mean (SD)) }\end{array}$} & \multirow{2}{*}{$\begin{array}{c}\text { Post test } \\
(\text { Mean (SD)) }\end{array}$} & $\begin{array}{c}\text { Mean } \\
\text { Difference }\end{array}$ & \multicolumn{2}{|c|}{ CI } & \multirow{2}{*}{$\boldsymbol{p}$ Value } \\
\cline { 4 - 6 } & & & Lower & \multicolumn{1}{|c|}{ Upper } & \\
\hline Nyeri & 6.8000 & 3.2667 & 3.53333 & 3,12175 & 3,94492 & 0,000 \\
& $(1.20712)$ & $(.88372)$ & & & & \\
\hline
\end{tabular}

\section{PEMBAHASAN}

Melalui Surat Keputusan Menteri Kesehatan tahun 2000 Puskesmas Kota Selatan Kota Gorontalo ditetapkan menjadi Puskesmas Kelas yang peresmiannya pada tanggal bersamaan dengan penggunaan nama Puskesmas Kota Selatan Kota Gorontalo dengan berkedudukan sebagai unit pelaksana pemerintah Kota Gorontalo dibidang pelayanan kesehatan masyarakat.

Adapun batas-batas wilayah Puskesmas Kota Selatan Kota Gorontalo yakni sebelah Utara berbatasan dengan Kecamatan Kota Tengah, sebelah Timur berbatasan dengan Kecamatan Kota Timur sebelah Selatan berbatasan dengan Kecamatan Hulondalangi dan sebelah http://ejurnal.ung.ac.id/index.php/jnj | 4 
Barat berbatasan dengan Kecamatan Kota Barat.

Intervensi stretching exercise dilakukan oleh peneliti sebanyak 1 kali/hari saat penelitian sesuai dengan tingkat kemampuan responden dalam waktu 15-20 menit. Hasil penelitian didapatkan bahwa dari 15 responden dengan osteoartritis sebelum diberikan perlakuan stretching exercise terdapat 7 $(46.7 \%)$ orang berada di kategori nyeri berat dan $8(53.3 \%)$ orang lainnya berada di kategori nyeri sedang dan setelah diberikan perlakuan terdapat perubahan atau penurunan tingkat nyeri yaitu 7 (46.7\%) orang berada di kategori nyeri sedang dan $8(53.3 \%)$ orang lainnya berada di kategori nyeri ringan. Sehingga didapatkan hasil analisa data yaitu nilai $t$ hitung sebesar 5,123 dengan Sig (2- talled) sebesar $0,000(<0,05)$ dan penurunan skala nyeri sesudah dilakukan stretching exercise dari 4,87 menjadi 3,87. Maka disimpulkan ada pengaruh pemberian terapi Stretching Exercise terhadap penurunan nyeri sendi lutut pada pasien Osteoartritis di Puskesmas Kota Selatan Kota Gorontalo.

Yandri (2011) mengemukakan bahwa Stretching Exercise merupakan salah satu terapi latihan untuk mempercepat penyembuhan dari suatu injuri/penyakit tertentu yang dalam pelaksanaanya mengunakan latihan latihan gerakan tubuh baik secara aktif maupun pasif (dalam Sari dan Pamungkas, 2011). Stretching merupakan suatu aktivitas meregangkan otot untuk meningkatkan fleksibilitas otot dan jangkauan gerakan persendian. The Crossfit Journal Article (2016) mengemukakan bahwa stretching sangat efektif dilakukan untuk meningkatkan fleksibilitas otot dan sendi sehingga dapat memberikan efek penurunan atau hilangnya rasa nyeri pada persendian. Latihan ini juga dapat meningkatkan aliran darah juga memperkuat tulang (dalam Rahmiati, 2017).

Latihan peregangan dapat dilakukan setiap hari sebelum memulai aktifitas pekerjaan melalui jalan ditempat selama 3-5 menit. Hal ini dapat memperlancar aliran darah pada area kaki dan membuat otot kaki lebih lentur. Latihan selanjutnya adalah dengan lengan melingkar selama 3-5 kali. Hal ini dapat memperlancar aliran darah pada area bahu dan punggung, serta melenturkan otot punggung dan lengan. Latihan peregangan yang lainya adalah dengan memfokuskan 
gerakan pada otot paha, perut, pergelangan kaki, pinggang, dan betis. Setelah dilakukan latihan peregangan selama 5-10 menit sebelum beraktifitas, otot akan merasa lebih rileks dan nyaman sehinga dapat terhindar dari cedera otot yang dapat menyebabkan rasa nyeri. Manfaat dari latihan peregangan yaitu meningkatkan kebugaran fisik dengan cara memperlancar transportasi zat-zat yang diperlukan tubuh dan pembuangan sisa-sisa zat yang tidak diperlukan oleh tubuh. Manfaat selanjutnya adalah mengoptimalkan gerakan, dengan cara mengulur otot-otot ligament, tendon, dan persendian sehingga dapat bekerja secara optimal (Suharjana, 2013).

Sejalan dengan penelitian Suhartono (2013), bahwa "dari 16 responden didapatkan nilai probabilitas $(\mathrm{P})$ $=0,000$ yang artinya terdapat pengaruh stretching exercise therapy terhadap tingkat nyeri sendi lutut dan tingkat mobilitas pada lansia”. Stimulus stretching exercise therapy akan mencapai otak terlebih dahulu sehingga menutup gerbang nyeri dan persepsi nyeri tidak muncul, dengan latihan teratur dapat memberikan manfaat untuk kebugaran tubuh dan sendi akan dapat melakukan pergerakan dengan baik terutama dalam kemampuan mobilisasi (Jabbour \& Sales, 2014). Menurut American College of Sports Medicine (ACSM) untuk mendapatkan hasil yang optimal dalam melakukan peregangan khususnya bagi penderita OA dibutuhkan waktu 15-20 menit untuk setiap pelaksanaannya dengan frekuensi tiga kali dalam seminggu (Suwardana, 2012).

Dari hasil penelitian terdapat satu orang yang mengalami penurunan tingkat nyeri yang signifikan yaitu sebelum intervensi stretching exercise berada dalam kategori skala nyeri berat dan setelah intervensi berubah menjadi skala ringan. Menurut peneliti kondisi ini disebabkan responden tersebut berada dalam rentang usia 25-35 tahun. Secara teori, usia 25-35 tahun merupakan usia produktif yang biasanya seseorang akan lebih banyak melakukan aktivitas fisik yang membutuhkan tenaga lebih untuk dapat menopang pekerjaannya. Sehingga menyebabkan ketegangan otot (kelelahan) hingga nyeri sendi pada lututnya (Price dan Wilson, 2013). Akan tetapi pada usia itu pula seseorang masih akan mengalami masa pertumbuhan termasuk dengan persendiannya sehingga proses 
penyembuhan akan lebih cepat dibandingkan dengan usia lanjut. Kekuatan otot pada manusia akan mencapai puncak pada usia 25-35 tahun, dan akan semakin menurun setelah melewati usia 35 tahun. Hal ini yang dapat menimbulkan potensi munculnya nyeri sesuai dengan perubahan postur tubuh dan degenerasi (Pratiwi, 2013).

Hal ini sejalan dengan penelitian Priono (2017) yang menjelaskan bahwa "dari hasil penelitian yang dilakukan pada petugas kebersihan di FIKK Universitas Muhamadiyah Yogyakarta didapatkan usia responden sebagian besar yaitu berusia antara 25-45 tahun sebanyak 14 responden $(53.8 \%)$ mengeluhkan nyeri muskuloskeletal dan setelah diberikan tindakan latihan peregangan, responden dengan rentang usia tersebut mengalami penurunan skala nyeri yang signifikan”.

Dari hasil observasi di lapangan diketahui juga bahwa responden dengan rentang usia 25-35 tahun memiliki berat badan atau IMT dalam kategori normal, sehingga peneliti berasumsi hal ini yang dapat menyebabkan nyeri pada bagian persendian mengalami penurunan setelah diberikan intervensi. Lailani (2013) menyatakan bahwa ketika berat badan semakin bertambah, tulang belakang akan tertekan untuk menerima beban yang membebani tersebut sehingga mengakibatkan timbulnya stres mekanis pada punggung bawah dan daerah sekitarnya. Hal yang dapat muncul ketika terdapat peningkatan IMT adalah kecenderungan munculnya tekanan pada otot, yang dapat menimbulkan rasa nyeri, terutama pada otot musculoskeletal.

Hasil ini juga sejalan dengan penelitian yang dilakukan oleh Mary Turner (1997) mengatakan bahwa orang yang menyempatkan melakukan oleh tubuh minimal 30 menit setiap harinya dapat memberikan keuntungan yang berlipat dan itu akan bertahan walaupun usia bertambah. Pemberian latihan stretching secara otomatis akan melatih kekuatan otot panggul dan kemudian otot menjadi kuat dan lentur sehingga nyeri akibat spasme otot dapat ditekan sedemikian rupa (dalam Sa'adah, 2013).

\section{SIMPULAN}

Setelah dilakukan terapi stretching exercise dari 15 responden didapatkan skala nyeri sendi lutut pada pasien Osteoartritis menurun dengan nilai terendah adalah 2 dengan kategori nyeri 
ringan (1-3) dengan nilai rata-rata (mean) 3.27. Analisa data dihasilkan nilai Sig (2talled) sebesar $0,000 \quad(<0,05)$. Maka disimpulkan Ho ditolak dan Ha diterima dengan demikian ada pengaruh pemberian terapi stretching exercise terhadap penurunan skala nyeri sendi lutut pada pasien Osteoartritis di Puskesmas Kota Selatan Kota Gorontalo.

Ahmed. (2012).

\section{DAFTAR PUSTAKA}

A Study On Prescribing Patterns In The Management of Arthtritis in the Departement of Orthopaedics. Scholar Research Libray.

Anelia, Nicky. (2013). Efektifitas Latihan

Kekuatan Otot Terhadap Kemampuan Mobilisasi Pasien dengan Fraktur di Ruang Rawat Anggrek Tengah Kanan RSUP Persahabatan.

Azkadina. (2017). Exercise Therapy. (https://www.dictio.id/t/apa-yangdimaksud-dengan-terapi-latihanpada-fisioterapi/12968).

Budiman. (2013). Penelitian Kesehatan.

Buku pertama. Bandung : PT Refika Aditama.

Defriyan. (2011). Faktor-faktor yang Berhubungan dengan Keluhan Nyeri Punggung Bawah pada Proses Penyulaman Kain Tapis di Sanggar Family Art Bandar
Lampung Tahun 2011. Skripsi. UIN Syarif Hidayatullah Jakarta. Handono. (2013). Hubungan Antara Penyesuaian Diri Dan Dukungan Sosial Terhadap Stres Lingkungan.

Helmi. (2012). Buku Ajar Gangguan Muskuloskeletal. Jakarta: Salemba Medika.

Ismayadi. (2014). Asuhan Keperawatan

Dengan Reumatik (Artritis Reumatoid) Pada Lansia.

Jabbour \& Sales. (2014). Prostalglandin

Receptor Signalling And Function in Human Endometrial Pathology.

Kawiyana. (2011). Interleukin-6 dan

Rank-ligand yang Tinggi Sebagai Faktor Resiko Terhadap Kejadian Osteoporosis Pada Wanita Pasca Menopause Defisiensi Estrogen. Program studi Ilmu Kedokteran Pasca Sarjana Universitas Udayana.

(http://download.portalgaruda.org/ article.php? article $=13182 \&$ val $=9$ 27).

Lailani, Tuti Marinus. (2013). Hubungan antara Peningkatan Indeks Massa Tubuh dengan Kejadian Nyeri Punggung Bawah pada Pasien Rawat Jalan di Poliklinik Saraf RSUD Dokter Soedarso Pontianak. Naskah Publikasi. FK Universitas Tanjungpura.

Lukman \& Ningsih. (2012). Asuhan

Keperawatan Pada Klien Dengan Gangguan Sistem Muskuloskeletal. Jilid 1. Jakarta : Salemba Medika. Notoadmodjo. (2012). Metodologi 
Penelitian Kesehatan. Jakarta : Rineka Cipta.

Nugraha. (2017). Prinsip Latihan

Penderita Osteoartritis.

Nurhidayah. (2012). Pengaruh Senam

$\begin{array}{lrr}\text { Rematik } & \text { Terhadap } & \text { Aktifitas } \\ \text { Fungsional } & \text { Lansia } & \text { Wilayah } \\ \text { Kelurahan } & \text { Nusukan } & \text { Banjarasi } \\ \text { Surakarta. } & & \end{array}$

Nursalam. (2012). Konsep dan Penerapan

Metodologi Penelitian Ilmu

Keperawatan. Jakarta : Salemba Medika.

Padila. (2013). Buku Ajar Keperawatan

Gerontik dilengkapi aplikasi kasus asuhan keperawatan gerontik, terapi modalitas, dan sesuai kompetensi standar. Nuha Medika: Yogyakarta.

Prasetyo. (2010). Konsep dan

Keperawatan Nyeri. Yogyakarta : Graha Ilmu.

Pratiwi, Mayrika. (2013). Beberapa Faktor Yang Berpengaruh Terhadap Keluhan Nyeri Punggung Bawah Pada Penjual Jamu Gendong. Jurnal Promosi Kesehatan Indonesia Vol. 4 / No. 1 / Januari 2013.

Price \& Wilson. (2013). Patofisiologi:

Konsep Klinis. Proses-Proses Penyakit. Jakarta: EGC.

Priono, Satrio Budi Raharjo. (2017).

Pengaruh Latihan Peregangan

(Stretching Exercise) Terhadap Nyeri Muskuloskeletal Akibat Keja Pada Petugas Kebersihan di FIKK Universitas Muhamadiyah Yogyakarta.
Rahmiati. (2017). Efektivitas Stretching terhadap Penurunan Nyeri sendi lutut Pada Lansia di UPTD Rumoh Seujahtera Geunaseh Sayang Banda Aceh. Jurnal Ilmu Keperawatan ISSN: 2338-6371.

Riskesdas. (2013). Laporan Hasil Riset Kesehatan Dasar.

Sa'adah, D. H. (2012). Pengaruh latihan Fleksi William (Stretching) terhadap tingkat nyeri punggung bawah pada lansia di Posyandu Lansia RW 2 Desa Kedungkandang Malang.

Sadikin. (2011). Penggunaan Obat yang Rasional. J Indon Med Assoc Volum:61 Nomor:4. Jakarta.

Sari \& Pamungkas. (2011). Pengaruh latihan gerak kaki (stretching) terhadap penurunan nyeri sendi ekstremitas bawah pada Lansia di Posyandu Lansia Sejahtera GBI Setia bakti Kediri.

Setiadi. (2012). Konsep dan Praktik Penulisan Riset Keperawatan. Jakarta : Graha Ilmu.

Sjamsuhidajat. (2011). Buku Ajar Ilmu Bedah, Edisi II. Jakarta : EGC.

Suharjana, Fredericus. (2013). Perbedaan pengaruh hasil latihan peregangan statis dan dinamis terhadap kelentukan togok menurut jenis kelamin anak kelas 3 dan 4 sekolah dasar. Jurusan Pendidikan Olahraga Fakultas Ilmu Keolahragaan Universitas Negeri Yogyakarta. Diakses 20 Januari 2018.

Suhartono. (2013). Pengaruh Stretching 
Exercise Therapy terhadap tingkat nyeri sendi lutut dan tingkat mobilitas pada lansia di Rumah Asuh Anak dan Lansia Griya Asih Lawang. Diakses 20 Januari 2018.

Suyanto. (2011). Metodologi dan Aplikasi

Penelitian Keperawatan.

Yogyakarta : Nuha Medika.

Suwardana, W. (2012). Pengaruh

pemberian latihan peregangan

terhadap penurunan nyeri pada

pasien iskhialgia di praktik

pelayanan keperawatan latu usadha Abiansemal Bandung.

WHO. (2016). Osteoarthritis. (online).

(http://www.who.int/medicines/are as/priority_medicines/BP6_12Oste o.pdf).

Wungouw, Herlina., Polii, Hedison, \&

Ibrahim,. C, Renold. (2015). Pengaruh

latihan peregangan terhadap

fleksibilitas lansia. Bagian

Fisiologi Fakultas Kedokteran

Universitas Sam Ratulangi

Manado.

Yudiyanta. (2015). Assessment Nyeri.

CSK-226/vol.42, no.3, tahun 2015.

(http://kalbemed.com/Portals/6/19_

226Teknik-

Assessment\%20Nyeri.pdf). 